\title{
Implementasi Model Pembelajaran IPA Berbasis Kearifan Lokal untuk Meningkatkan Kreativitas dan Hasil Belajar Siswa
}

\author{
Aji Pamungkas ${ }^{1}$ *, Bambang Subali ${ }^{1}$, Suharto Lunuwih ${ }^{1}$ \\ ${ }^{1}$ Program Studi Pendidikan Fisika, Universitas Negeri Semarang. Kampus Sekaran, Gunungpati \\ Semarang 50229, Indonesia \\ * Corresponding Author. E-mail: ajipamungkas07@gmail.com, Telp: +6285642521206 \\ Received: 21 June 2017; Revised:30 August 2017; Accepted: 9 October 2017
}

\begin{abstract}
Abstrak
Penelitian ini mengangkat nilai kearifan lokal kalender pranata mangsa yang sudah tertanam di masyarakat Jawa khususnya daerah Gunungpati. Tujuan dari penelitian ini adalah untuk mengetahui pengaruh dan peningkatan dari implementasi model pembelajaran IPA berbasis kearifan lokal terhadap kreativitas dan hasil belajar siswa. Metode penelitian ini menggunakan quasi eksperimen. Sampel penelitian ini adalah kelas VII F sebagai kelas eksperimen dan VII B sebagai kelas kontrol di SMP Negeri 22 Semarang. Pemilihan sampel menggunakan teknik purposive sampling. Aspek kreativitas yang diteliti terdiri atas kelancaran, keaslian, kesadaran dan ingatan yang diukur dengan lembar observasi. Hasil belajar siswa diukur dengan pretest dan posttest. Hasil Teknik analisis data menggunakan uji independent sample t-test didapatkan signifikansi data hasil belajar siswa sebesar $0,000<0,05$. Artinya ada perbedaan hasil belajar siswa yang signifikan antara kelas eksperimen dan kelas kontrol. Besar peningkatan hasil belajar siswa pada kelas kontrol sebesar 0,56 kategori sedang, sedangkan pada kelas eksperimen sebesar 0,70 kategori sedang. Besar peningkatan kreativitas siswa pada kelas kontrol sebesar 0,32 kategori sedang, sedangkan pada kelas eksperimen sebesar 0,46 kategori sedang. Hasil penelitian ini membuktikan bahwa dengan model pembelajaran IPA berbasis kearifan lokal dapat meningkatkan kreativitas dan hasil belajar siswa.
\end{abstract}

Kata Kunci: model pembelajaran IPA berbasis kearifan lokal, kalender pranata mangsa, kreativitas, hasil belajar

\section{Implementation of Science Learning Model Based on Local Wisdom to Improve Creativity and Student Learning Outcomes}

\begin{abstract}
The aim of this study is to reveal the effect of the implementation of science learning model based on local wisdom to improve creativity and student learning outcomes, as well as knowing the magnitude of improvement. This research method uses quasi-experiment. The sample of this research is class VII F as an experimental class and VII B as control class in SMP Negeri 22 Semarang. Sample selection using purposive sampling technique. The aspects of creativity were constructing fluency, originality, awareness, and memory. Data were analyzed using independent sample t-test test the significance of the data obtained in student learning outcomes of $0.003<0.05$ and the significance of the observation data from the creativity of $0.003<0.05$. This means that there are differences in creativity and student learning outcomes significantly between the experimental class and control class. Great improvement of student learning outcomes in the control class of 0.56 which are medium category, while in the experimental class of 0.68 which are medium category. Great improvement of students' creativity in the control class of 0.55 which are medium category, while in the experimental class of 0.71 which are high category. The results of this study prove that the science learning model based on local wisdom can improve creativity and student learning outcomes. This study the value of local wisdom that is Calendar Pranata Mangsa already embedded in the Java community.
\end{abstract}

Keywords: science learning model based on local wisdom, pranata mangsa calendar, creativity, learning outcomes.

How to Cite: Pamungkas, A., Subali, B., \& Linuwih, S. (2017). Implementasi model pembelajaran IPA berbasis kearifan lokal untuk meningkatkan kreativitas dan hasil belajar siswa. Jurnal Inovasi Pendidikan IPA, 3(2), 118127. doi:http://dx.doi.org/10.21831/jipi.v3i2.14562 


\section{Jurnal Inovasi Pendidikan IPA, 3 (2), 2017 - 119}

Aji Pamungkas, Bambang Subali, Suharto Lunuwih

\section{PENDAHULUAN}

Pendidikan ilmu pengetahuan alam (IPA) adalah suatu upaya atau proses membelajarkan siswa agar memahami hakikat IPA yang meliputi: produk, proses, dan mengembangkan sikap ilmiah serta sadar akan nilai-nilai yang ada dalam masyarakat untuk pengembangan sikap dan tindakan berupa aplikasi IPA yang positif. Tujuan dari pendidikan sains/IPA meliputi: Pengetahuan dan pemahaman, penggalian dan penemuan, imajinasi dan kreativitas, sikap dan ilmiah, dan penerapan (Mariana \& Praginda, 2009, p. 27). Model pembelajaran IPA dalam menyampaikan materi IPA memiliki karakteristik khusus (Wisudawati \& Sulistyowati, 2014, p. 49). Karakteristik khusus dalam materi IPA yaitu mempelajari fenomena alam yang faktual (factual), baik berupa kenyataan (reality), atau kejadian (events) dan hubungan sebab-akibat (Wisudawati \& Sulistyowati, 2014, p. 30).

Model pembelajaran IPA yang disesuaikan dengan kurikulum 2013 terdiri atas beberapa model pembelajaran seperti model pembelajaran inquiry, problem based learning dsb. Setiap model pembelajaran tersebut memberikan efek pembelajaran dan efek pengiring (Trianto, 2007, p. 29). Efek pembelajaran dan efek pengiring merupakan komponen dari model pembelajaran IPA (Hamid, 2011). Efek pembelajaran adalah hasil belajar yang diperoleh siswa setelah melalui proses pembelajaran, sedangkan efek pengiring adalah nilai karakter yang diharapkan muncul setelah melalui proses pembelajaran. Model pembelajaran IPA berbasis kearifan lokal adalah salah satu model pembelajaran IPA yang berorientasi pada integrasi nilai-nilai kearifan lokal (local wisdom) suatu masyarakat ke dalam materi pembelajaran IPA. Menurut Wibowo \& Gunawan (2015, p. 125) kearifan budaya lokal sangat tepat untuk membangun nilai karakter siswa yang merupakan efek pengiring dalam suatu pembelajaran di sekolah.

Kearifan lokal merupakan buah atau hasil dari masyarakat/etnis tertentu melalui pengalaman mereka dan belum tentu dialami oleh masyarakat lain. Kearifan lokal melekat sangat kuat pada masyarakat/etnis tertentu, karena nilai kearifan lokal teruji dan melalui proses panjang, bahkan usianya hampir menyamai keberadaan sebuah masyarakat atau etnis tertentu (Wibowo \& Gunawan, 2015, p. 17).

Suastra, Tika, \& Kariasa (2011) menyatakan bahwa nilai-nilai kearifan lokal saat ini diabaikan dalam pembelajaran khususnya pembelajaran sains/IPA di sekolah. Upaya penelitian yang dilakukan oleh Laurent et al., (2014, p. 575) menyatakan dalam merencanakan pembelajaran yang berbasis kearifan lokal melalui implementasi model pembelajaran dengan pendekatan saintifik. Pendekatan saintifik merupakan pendekatan dalam model pembelajaran IPA yang menuntun siswa berpikir sistematis sebagaimana para saintis (ilmuwan) dimulai dari mengamati, menanya, mencoba, menalar, dan mengomunikasikan (Wibowo \& Gunawan, 2015, p. 128).

Hasil penelitian Suastra, Tika, \& Kariasa (2011, p. 11) dalam mendesain model pembelajaran sains berbasis budaya lokal memiliki 5 tahapan yaitu kegiatan awal, eksplorasi, elaborasi, konfirmasi, dan kegiatan akhir. Penelitian Suastra, Tika, \& Kariasa, (2011) juga menunjukkan adanya peningkatan prestasi belajar dan kinerja ilmiah siswa SMP di Bali yang dilakukan dengan membandingkan kelas eksperimen dan kelas kontrol. Menurut Setiawan (2014, p. 1) Pembelajaran Sains tidak hanya teoritis saja, tetapi juga mengaitkan dengan keadaan permasalahan nyata yang terjadi di kehidupan nyata. Pesatnya perkembangan IPA dalam berbagai bidang kehidupan masyarakat, menuntut cara pembelajaran yang dapat menyiapkan siswa untuk memahami IPA, yang mampu berpikir logis, kreatif, serta beragumentasi yang benar.

Upaya yang dilakukan oleh Subali, Sopyan, \& Ellianawati (2015, p. 4) dalam mendesain pembelajaran sains berbasis kearifan lokal (local wisdom) menunjukan adanya peningkatan 11 karakter positif siswa, dengan karakter positif yang paling signifikan adalah karakter jujur, disiplin, teliti, rajin, hati-hati, tanggung jawab, dan peduli lingkungan. Kreativitas atau imajinasi adalah salah satu dimensi dari pendidikan sains dewasa ini. Kreativitas berhubungan dengan kemampuan memvisualisasikan atau menghasilkan gambaran objek dan gagasan dengan cara-cara baru, memecahkan masalah dan teka-teki, menghasilkan ide atau gagasan yang tidak biasa atau unik (Mariana \& Praginda, 2009, p. 28).

Upaya penelitian yang dilakukan oleh Lee \& Erdogan (2007) tentang pengaruh pendekatan STS (Sains, Technology, Society) pada sikap siswa terhadap ilmu dan kreativitasnya, peningkatannya masih kurang signifikan dari 3 aspek penilaian kreativitas yaitu pertanyaan, penalaran, dan memprediksi solusi. Menurut $\mathrm{Hu}$ et al. (2013, p. 4) komponen utama dalam kreativitas siswa adalah ilmu pengetahuan dan keterampil- 
annya. Peningkatan Kreativitas siswa dipengaruhi oleh pembelajaran yang dilaksanakan. Menurut (Hu \& Adey, 2002) merangsang berpikir kreatif siswa dengan cara pembelajaran yang bebas, tebuka, dan positif. Kreativitas siswa yang merupakan dimensi dari pendidikan IPA saat ini perlu ditingkatkan. Oleh karena itu, perlu adanya model pembelajaran yang mampu mengakomodasi kreativitas siswa tersebut. Selain dimensi kreativitas yang berpengaruh dalam pendidikan IPA, hasil belajar yang merupakan ranah kognitif adalah tujuan utama dari pendidikan IPA yang digunakan sebagai instrumen evaluasi pengetahuan siswa. Hasil belajar adalah kemampuan anak yang diperoleh anak setelah melakukan kegiatan pembelajaran.

Berdasarkan hasil observasi di SMP N 22 Semarang, ketuntasan siswa setelah melalui proses pembelajaran berdasarkan nilai UTS masih tergolong rendah. Dari 36 siswa pada kelas VII $F$ hanya 15 siswa yang lulus KKN dengan persentase 41,67. Hal ini menunjukkan ketuntasan siswa yang masih rendah di sekolah tersebut terhadap hasil belajar IPA. Berdasarkan hasil penelitian sebelumnya dan penjelasan di atas mendorong peneliti untuk melakukan penelitian dengan judul "Implementasi Model Pembelajaran IPA berbasis Kearifan Lokal pada Siswa SMP untuk Meningkatkan Kreativitas dan Hasil Belajar Siswa".

Berdasarkan latar belakang masalah tersebut, rumusan masalah dalam penelitian ini adalah (1) bagaimana pengaruh implementasi model pembelajaran IPA berbasis kearifan lokal terhadap kreativitas dan hasil belajar siswa, (2) Berapa besar peningkatan kreativitas dan hasil belajar siswa setelah diterapkan model pembelajaran IPA berbasis kearifan lokal, Berkaitan dengan masalah ini, maka dipandang perlu untuk menimplementasikan model pembelajaran IPA berbasis kearifan lokal dalam upaya meningkatkan kreativitas siswa.

Model pembelajaran IPA berbasis kearifan lokal dalam penelitian ini memiliki sintaks pembelajaran yaitu (1) Review (penjajakan) (2) Task (penugasan) (3) Solution (pemecahan masalah) (4) Reflection (refleksi), (5) Evaluation (evaluasi) (Subali et al., 2015). Sintaks pembelajaran ini dikembangkan agar kreativitas dan hasil belajar siswa meningkat.

\section{METODE}

Penelitian ini menggunakan jenis penelitian Quasi Experimental dengan Nonequivalent Control Group Desain. Terdapat dua kelas yang digunakan dalam penelitian ini yaitu: kelas eksperimen dan kelas kontrol. Penggunaan metode ini bertujuan untuk mengetahui pengaruh sebuah perlakuan terhadap objek yang diteliti (Sugiyono, 2015, pp. 74-75). Rancangan ini terdiri atas dua uji yaitu pretest dan posttest, pretest yang dilakukan sebelum perlakuan diberikan dan postest setelah perlakuan diberikan. Desain dapat digambarkan pada Tabel 1.

Tabel 1. Desain Penelitian

\begin{tabular}{cccc}
\hline Kelas & Pre-Test & Perlakuan & Post-Test \\
\hline Eksperimen & $\mathrm{O}_{1}$ & $\mathrm{X}_{1}$ & $\mathrm{O}_{2}$ \\
Kontrol & $\mathrm{O}_{3}$ & $\mathrm{X}_{2}$ & $\mathrm{O}_{4}$ \\
\hline
\end{tabular}

Pengaruh perlakuan adalah: $\left(\mathrm{O}_{2}-\mathrm{O}_{1}\right)-\left(\mathrm{O}_{4}-\mathrm{O}_{3}\right)$

Keterangan:

$\mathrm{X}_{1}$ : perlakuan yang diberikan kepada kelas eksperimen adalah pembelajaran dengan model pembelajaran IPA berbasis kearifan lokal

$\mathrm{X}_{2}$ : perlakuan yang diberikan kepada kelas kontrol adalah pembelajaran dengan menggunakan pembelajaran IPA dengan pendekatan saintifik.

$\mathrm{O}_{1}$ : tes awal (pretest) yang diberikan kepada kelas eksperimen

$\mathrm{O}_{2}$ : tes akhir (posttest) yang diberikan kepada kelas eksperimen

$\mathrm{O}_{3}$ : tes awal (pretest) yang diberikan kepada kelas kontrol

$\mathrm{O}_{4}$ : tes akhir (posttest) yang diberikan kepada kelas kontrol

Penelitian ini dilaksanakan pada Bulan April-Mei 2017 Semester Genap Tahun Pelajaran 2016/2017. Teknik pengambilan sampel pada penelitian ini menggunakan teknik sampling purposive. Sampel penelitian ini adalah siswa kelas VII di SMP Negeri 22 Semarang. Prosedur penelitian meliputi studi pendahuluan di SMP Negeri 22 Semarang, pembuatan perangkat dan instrumen penelitian, tahap implementasi serta analisis data dan pembahasan.

Data yang dikumpulkan dalam penelitian ini meliputi nilai pretest dan nilai observasi observasi siswa, dan nilai posttest Data penelitian ini dikumpulkan melalui tes dan observasi.

Teknik pengolahan data terdiri atas uji homogenitas, uji normalitas nilai pretest dan posttest. Uji t-test untuk mengetahui adanya pengaruh model pembelajaran terhadap hasil belajar siswa. Uji lembar observasi untuk mengetahui peningkatan kreativitas siswa.dan uji N-Gain untuk mengetahui besar peningkatan kreativitas siswa. Instrumen penelitian terdiri 
atas rencana pelaksanaan pembelajaran, lembar kerja siswa, lembar soal dan lembar observasi.

\section{HASIL DAN PEMBAHASAN}

\section{Hasil}

Hasil penelitian ini adalah data kuantitatif yang dianalisis terdiri atas tahap awal dan tahap akhir. Tahap awal terdiri atas uji normalitas dan uji homogenitas, sedangkan tahap akhir terdiri atas uji t-test, uji lembar observasi dan uji gain ternormalisasi.

Analisis data tahap awal penelitian ini adalah untuk menguji homogenitas dan uji normalitas data. Berdasarkan analisis data menggunakan IBM SPSS Statistic 22 diperoleh hasil uji homogenitas pada Tabel 2.

Tabel 2. Output SPSS Uji Homogenitas

\begin{tabular}{ccc}
\hline Data & $\begin{array}{c}\text { Nilai } \\
\text { Signifikansi }\end{array}$ & Kriteria \\
\hline $\begin{array}{c}\text { Nilai Pretest } \text { Siswa Kelas } \\
\text { Eksperimen }\end{array}$ & 0,237 & Homogen \\
\hline $\begin{array}{c}\text { Nilai Pretest Siswa Kelas } \\
\text { Kontrol }\end{array}$ & 0,668 & Homogen \\
\hline
\end{tabular}

Tabel 2 memberikan informasi apakah varians dari kelompok yang dibandingkan adalah sama. Syaratnya adalah nilai signifikansi harus lebih dari 0,05. Tabel 2 menunjukkan nilai signifikansi nilai pretest didapatkan sebesar $0,237>0,05$ dan signifikansi nilai posttest sebesar 0,668. Artinya, data penelitian ini bisa dikatakan homogen (seragam) antara kelas eksperimen (VII F) dan kelas kontrol (VII B). Kemudian pada tahap awal ini dilakukan uji normalitas nilai pretest dan posttest menggunakan uji Kolmogorov-Smirnov dengan banguan aplikasi IBM SPSS Statistics 22. Hasil perhitungan uji normalitas dapat dilihat pada Tabel 3.

Tabel 3. Output SPSS Uji Normalitas

\begin{tabular}{ccc}
\hline Kelas & Data & Nilai Signifikansi \\
\hline Eksperimen & \multirow{2}{*}{ Pretest } & 0,097 \\
Kontrol & & 0,077 \\
Eksperimen & \multirow{2}{*}{ Posttest } & 0,200 \\
Kontrol & & 0,148 \\
\hline
\end{tabular}

Tabel 3 memberikan informasi data berdistribusi normal dengan memperhatikan nilai signifikansi data (p). Tabel 3 menunjukkan angka signifikansi data. (p) kedua kelas untuk data pretest sebesar 0,097 dan 0,077, dan untuk data posttest kedua kelas nilai signifikansi (p) sebesar 0,200 dan 0,148 . Nilai signifikansi (p) data kedua kelas menunjukkan $>0,05$, Maka dapat disimpulkan, data sampel kedua kelas berasal dari populasi yang berdistribusi normal.
Analisis data tahap akhir meliputi uji ttest, uji lembar observasi dan uji gain ternormalisasi. Analisis data hasil kreativitas dan belajar siswa menggunakan uji t-test. Hasil belajar siswa adalah nilai posttest kedua kelas sampel dan hasil kreativitas siswa adalah nilai observasi. Uji $t$-test digunakan untuk mengetahui adanya pengaruh model pembelajaran IPA berbasis kearifan lokal terhadap peningkatan hasil belajar siswa. Hipotesis yang diuji adalah sebagai berikut.

Ho $=$ Model pembelajaran IPA berbasis kearifan lokal tidak dapat meningkatkan hasil belajar siswa.

$\mathrm{Ha}=$ Model pembelajaran IPA berbasis kearifan lokal dapat meningkatkan hasil belajar siswa.

Uji hipotesis dilakukan untuk melihat perbedaan hasil belajar siswa pada kelas eksperimen dan kelas kontrol. Data yang digunakan pada uji t-test adalah nilai posttest siswa kedua sampel, uji t-test menggunakan uji independent sample t-test dengan bantuan aplikasi IBM SPSS Statistics 22. Data berdistribusi normal maka uji independent samples t-test bisa langsung dilakukan. Hasil perhitungan dapat dilihat pada Tabel 7 dan Tabel 8.

Tabel 4. Output SPSS Independent Samples Test

\begin{tabular}{clcc}
\hline Data & Sig & Sig. 2-tailed & $\begin{array}{c}\text { Mean } \\
\text { Differences }\end{array}$ \\
\hline Hasil Belajar & 0,102 & 0,000 & 9,5 \\
\hline
\end{tabular}

Tabel. 5 Output SPSS Hasil Deskripsi Statistik

\begin{tabular}{ccccc}
\hline Data & Kelas & \multicolumn{2}{c}{ N Mean } & Std. Deviation \\
\hline \multirow{2}{*}{ Hasil Belajar } & Eksperimen 36 & 78,4 & 8,91 \\
& Kontrol & 36 & 68,9 & 10,8 \\
\hline Melalui & uji & perbedaan & independent
\end{tabular}
samples t-test (Sufren \& Natanael, 2014), terbukti ada perbedaan hasil belajar siswa yang signifikan antara model pembelajaran IPA berbasis kearifan lokal dan model pembelajaran IPA pendekatan saintifik, signifikansi hasil belajar $(p)=0,000<0,05$. Hasil belajar siswa dengan model pembelajaran IPA berbasis kearifan lokal $(\mathrm{M}=76,03 ; \mathrm{SD}=8,742)$ lebih tinggi dari pada hasil belajar siswa dengan model pembelajaran IPA melalui pendekatan saintifik $(M=68,93 ; \mathrm{SD}=10,781)$. Dapat disimpulkan bahwa melalui uji independent samples t-test maka Ha diterima yaitu model pembelajaran IPA berbasis kearifan lokal dapat meningkatkan hasil belajar siswa.

Analisis selanjutnya adalah analisis kreativitas menggunakan uji lembar observasi yang 
dilakukan oleh observer. Observer adalah mahasiswa berjumlah enam orang. Pengamatan selama tiga kali pertemuan dilakukan ketika siswa sedang berdiskusi dan menjawab pertanyaan dari diskusi. Pertanyaan diskusi tersebut memuat aspek kreativitas yang diteliti. Perbandingan rata-rata nilai kreativitas siswa kelas eksperimen dan kelas kontrol disajikan pada Gambar 1.

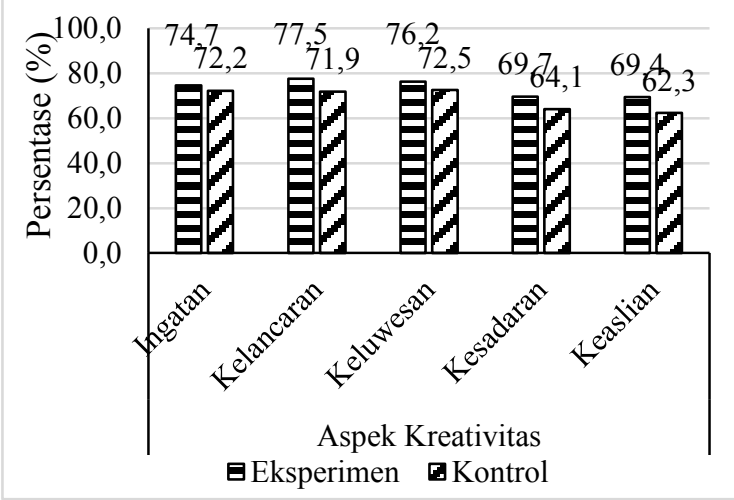

Gambar 1. Perbandingan Rata-rata Nilai Kreativitas Siswa Antara Kelas Eksperimen dan Kelas Kontrol

Analisis data selanjutnya yaitu uji gain ternormalisasi untuk mengetahui besarnya peningkatan kreativitas siswa pada kelas eksperimen dan kelas kontrol. Data yang digunakan adalah nilai lembar observasi siswa di kedua kelas. Hasil uji gain untuk aspek kreativitas kelas eksperimen dan kelas kontrol dapat dilihat pada Tabel 6 dan 7.

Tabel 6. Hasil Uji N Gain Aspek Kreativitas Kelas Eksperimen

\begin{tabular}{|c|c|c|c|c|}
\hline \multirow{2}{*}{$\begin{array}{c}\text { Aspek } \\
\text { Kreativitas }\end{array}$} & \multicolumn{4}{|c|}{$\langle g\rangle$ Pertemuan ke- } \\
\hline & $1 \& 2$ & $2 \& 3$ & $1 \& 3$ & Rata-rata \\
\hline Kelancaran & 0,40 & 0,62 & 0,78 & 0,60 \\
\hline Keluwesan & 0,35 & 0,58 & 0,73 & 0,55 \\
\hline Kesadaran & 0,26 & 0,46 & 0,60 & 0,44 \\
\hline Ingatan & 0,32 & 0,31 & 0,53 & 0,38 \\
\hline Keaslian & 0,33 & 0,20 & 0,47 & 0,33 \\
\hline Rata-rata & 0,33 & 0,43 & 0,62 & 0,46 \\
\hline
\end{tabular}

Tabel 7. Hasil Uji N Gain Aspek Kreativitas Kelas Kontrol

\begin{tabular}{ccccc}
\hline Aspek & \multicolumn{4}{c}{$\langle\boldsymbol{g}\rangle$ Pertemuan ke- } \\
\cline { 2 - 5 } Kreativitas & $\mathbf{1 \& 2}$ & $\mathbf{2 \& 3}$ & $\mathbf{1 \& 3}$ & Rata-rata \\
\hline Kelancaran & 0,51 & 0,25 & 0,63 & 0,46 \\
Keluwesan & 0,34 & 0,22 & 0,49 & 0,35 \\
Kesadaran & 0,28 & 0,15 & 0,15 & 0.25 \\
Ingatan & 0,39 & 0,04 & 0.41 & 0,28 \\
Keaslian & 0,22 & 0,15 & 0,34 & 0,24 \\
Rata-rata & 0,35 & 0,16 & 0,46 & $\mathbf{0 , 3 2}$ \\
\hline
\end{tabular}

Berdasarkan Tabel 6 dan 7 hasil uji gain ternormalisasi menunjukkan rata-rata indikator aspek kreativitas siswa pada kelas eksperimen mengalami peningkatan sebesar 0,46 dengan kategori sedang. Pada kelas kontrol mengalami peningkatan sebesar 0,32 dengan kategori sedang. Hal ini menunjukkan bahwa model pembelajaran IPA berbasis kearifan lokal yang diterapkan pada kelas eksperimen dapat meningkatkan kreativitas siswa yang lebih tinggi daripada model pembelajaran saintifik yang diterapkan pada kelas kontrol.

Analisis data selanjutnya yaitu besar peningkatan hasil belajar siswa pada kelas eksperimen dan kelas kontrol. Hasil uji gain ternormalisasi untuk hasil belajar siswa pada kelas eksperimen dan kelas kontrol dapat dilihat pada Tabel 8 .

Tabel 8. Hasil Uji N Gain Hasil Belajar

\begin{tabular}{lcccl}
\hline \multicolumn{1}{c}{ Kelas } & $\begin{array}{c}\overline{\boldsymbol{x}} \text { Pre- } \\
\text { Test }\end{array}$ & $\begin{array}{c}\overline{\boldsymbol{x}} \text { Post- } \\
\text { Test }\end{array}$ & $<$ g $>$ & Kategori \\
\hline Eksperimen & 27,00 & 78,42 & 0,70 & Sedang \\
Kontrol & 29,63 & 68,93 & 0,56 & Sedang \\
\hline
\end{tabular}

\section{Pembahasan}

Salah satu pokok bahasan mata pelajaran IPA kelas VII SMP Kurikulum 2013 adalah materi tata surya. Materi tata surta memiliki beberapa kompetensi dasar. Pada penelitian ini membahas materi tata surya sub materi gerak rotasi dan revolusi Bumi. Jenis percobaan yang terdapat pada materi tata surya dalam penelitian ini adalah (1) rotasi bumi, (2) pemodelan orbit planet, (3) revolusi bumi.

Model pembelajaran IPA berbasis kearifan lokal juga berpengaruh terhadap siswa pada kelas eksperimen dengan nilai rata-rata kreativitas siswa lebih tinggi daripada nilai rata-rata kreativitas siswa pada kelas kontrol, maka akan dilakukan pembahasan mengenai hal tersebut serta pembahasan berapa besar peningkatan kreativitas dan hasil belajar siswa.

Pembelajaran yang telah diretapkan pada kelas eksperimen memberikan pengaruh terhadap kreativitas dan hasil belajar siswa. Upaya untuk mengukur pengaruhnya, sebelum memberikan perlakuan peneliti memberikan pretest pada kelas eksperimen dan kelas kontrol untuk mengukur keadaan awal kelas. Kemudian pada akhir pertemuan diuji dengan lembar posttest untuk mengetahui keadaan akhir kelas. Hasil pretest yang telah dilaksanakan memiliki ratarata 27,0 pada kelas eksperimen dan 29,6 pada kelas kontrol. Rata-rata nilai posttest kedua kelas yaitu 78,4 untuk kelas eksperimen dan 68,9 untuk kelas kontrol. 
Pengaruh model pembelajaran IPA berbasis kearifan lokal terhadap hasil belajar siswa diukur dengan uji t-test data nilai posttest Berdasarkan perhitungan uji independent samples ttest menggunakan aplikasi IBM SPSS Statistics 22 mendapatkan signifikansi data nilai posttest sebesar $0,000<0,05$. Jadi dapat disimpulkan bahwa model pembelajaran IPA berbasis kearifan lokal dapat hasil belajar siswa.

Berdasarkan hasil t-test diketahui bahwa implementasi model pembelajaran IPA berbasis kearifan lokal berpengaruh terhadap hasil belajar siswa. Hasil $t$-test dapat dilihat pada Tabel 4 menunjukkan bahwa terdapat signifikan antara model pembelajaran IPA berbasis kearifan lokal dengan model pembelajaran pendekatan saintifik terhadap hasil belajar siswa. Signifikansi disini berarti terdapat perbedaan aktivitas siswa sebelum dan sesudah diberi perlakuan yaitu implementasi model pembelajaran IPA berbasis kearifan lokal dalam pembelajaran.

Pengaruh implementasi model pembelajaran IPA berbasis kearifan lokal terhadap kreativitas yang pertama dari hasil posttest. Tes dalam bentuk soal uraian yang membuat siswa berpikir divergen atau meluas untuk menggabungkan beberapa ide terkait pemahaman konsep materi pembelajaran dengan kearifan lokal kalender pranata mangsa.

Hasil penelitian menunjukkan bahwa nilai posttest pada kelas eksperimen lebih tinggi dibandingkan pada kelas kontrol. Perbedaan nilai rata-rata posttest yang signifikan pada kelas eksperimen dan kelas kontrol diakibatkan dari pengaruh dari proses pembelajaran siswa di kelas eksperimen. Pembelajaran pada kelas eksperimen yang menggabungkan materi pembelajaran dengan kearifan lokal dapat memberikan pengalaman kepada siswa yang lebih luas, dibandingkan dengan model pembelajaran pendekatan saintifik. Hal ini sesuai dengan pendapat dari Canadian Council on Learning (2008) pengalaman yang luas dapat membantu siswa mendapatkan keterampilan berpendapat dan kedewasaan. Pada kelas eksperimen jawaban siswa yang lebih luas dan perspektif terhadap objek permasalahan materi rotasi dan revolusi Bumi dalam sudut pandang ilmu sebagai hasil pengetahuan sains dan sebagai hasil pengetahuan masyarakat.

Perbedaan nilai rata-rata posttest yang signifikan antara kelas eksperimen dan kelas kontrol juga menunjukkan dengan model pembelajaran IPA berbasis kearifan lokal dapat meningkatkan hasil belajar siswa dimana siswa lebih mampu memecahkan masalah ketika mengerjakan soal tersebut. Dapat dilihat dari indikator hasil belajar yaitu memiliki sikap yang mampu memecahkan permasalahan yang disajikan dalam soal tersebut. Hal ini sependapat dengan Mungmachon (2012) melalui kearifan dan pengetahuan lokal yang terintegrasi dalam ilmu pengetahuan alam mampu memecahkan suatu permasalahan.

Pengaruh model pembelajaran yang menggunakan metode percobaan dan eksperimen pada kedua kelas juga menunjukkan peningkatan pada hasil belajar siswa. Hal ini sejalan dengan penelitian yang dilakukan oleh Subekti \& Ariswan (2016) melalui pembelajaran fisika menggunakan metode eksperimen mampu meningkatkan hasil belajar kognitif siswa.

Pengaruh model pembelajaran IPA berbasis kearifan lokal terhadap kreativitas siswa dapat dilihat dari hasil observasi ketika pembelajaran. Kreativitas siswa ketika pembelajaran diteliti ketika siswa berdiskusi dan menjawab pertanyaan diskusi yang disajikan di lembar kegiatan siswa. Observasi kreativitas siswa tidak hanya dilakukan pada satu kali pertemuan melainkan dilakukan setiap pertemuan. Hal tersebut dilakukan untuk mengetahui peningkatan kreativitas siswa dari pertemuan ke pertemuan.

Hasil penelitian menunjukkan bahwa kreativitas siswa pada kelas eksperimen lebih tinggi dibandingkan pada kelas kontrol. Hasil analisis data menunjukkkan rata-rata hasil observasi aspek kreativitas siswa pada kelas eksperimen sebesar 73,5 sedangkan pada kelas kontrol sebesar 68,6.

Implementasi model pembelajaran IPA berbasis kearifan lokal memberikan kesempatan kepada siswa untuk mengembangkan kreativitasnya. Siswa menjadi aktif dalam proses pembelajaran dengan diterapkannya model pembelajaran IPA berbasis kearifan lokal melalui diskusi dan melakukan percobaan. Diskusi memberikan kesempatan kepada siswa untuk memberikan ide/gagasannya serta mendorong untuk lebih aktif sehingga kreativitas berpikir siswa menjadi berkembang. Hal ini sejalan dengan hasil penelitian Utami, Noviar, \& Agustina (2012) yang menunjukkan bahwa penerapan model pembelajaran sains berbasis kearifan lokal dengan teknik klarifikasi nilai dapat meningkatkan kreativitas berpikir siswa.

Hasil analisis data menunjukkan untuk setiap indikator aspek kreativitas siswa kelas eksperimen lebih tinggi dibandingkan kelas kontrol. Peningkatan kreativitas siswa juga 
terlihat semakin meningkat dari pertemuan ke pertemuan. Hal ini disebabkan karena pada pertemuan pertama siswa masih menyesuaikan dengan model pembelajaran IPA berbasis kearifan lokal yang diterapkan, namun pada pertemuan kedua dan ketiga siswa telah mampu mengikuti dengan baik sehingga hasil kreativitas siswa menunjukkan peningkatan. Kegiatan diskusi yang dilakukan dalam pembelajaran memberikan kesempatan yang lebih banyak kepada siswa untuk mengembangkan kreativitas berpikir. Hal ini serupa dengan penelitian Subagia \& Wiratma (2008) aktivitas dan kreativitas siswa akan lebih tinggi ketika siswa melakukan diskusi atau percobaan dalam kelompok daripada ketika siswa hanya menerima informasi dari guru (metode ceramah).

Hasil penelitian menunjukkan bahwa observasi kreativitas yang mencakup indikator aspek kreativitas yang meliputi aspek kelancaran, keaslian, keluwesan, kesadaran dan ingatan meningkat secara signifikan pada kelas eksperimen. Peningkatan paling signifikan yang diperoleh oleh siswa adalah pada pertemuan ke tiga yaitu ketika membahas materi revolusi Bumi. Persentase rata-rata aspek kreativitas siswa pada kelas eksperimen mengalami peningkatan sebesar 85,1. Sedangkan pada kelas kontrol peningkatan sebesar 76,6. Persentase rata-rata aspek kreativitas siswa pada kelas eksperimen yang lebih tinggi menunjukkan impelementasi model pembelajaran IPA berbasis kearifan lokal dapat meningkatkan kreativitas siswa. Hal ini sejalan dengan penelitian yang dilakukan oleh Suastra \& Yasmini (2013) melalui implementasi model pembelajaran sains berbasis kearifan lokal dapat mengembangkan kreativitas berpikir siswa dan karakter bangsa. Penelitian yang dilakukan Suastra \& Yasmini (2013) aspek kreativitas yang dapat dikembangkan dalam implementasi model pembelajaran sains berbasis kearifan lokal adalah aspek kelancaran, keluwesan dan keaslian.

Perbedaan rata-rata hasil observasi yang cukup signifikan pada kedua kelas dikarenakan beberapa aspek kreativitas siswa yang diteliti memiliki rata-rata yang signifikan sekali yaitu aspek kelancaran, kesadaran. Hal ini dikarenakan penggunaan kalender pranata mangsa yang digunakan pada kelas eksperimen membuat siswa lebih lancar dalam memprediksi perubahan musim, dan membuat sikap peduli lingkungan lebih tinggi dari kelas kontrol. Akan tetapi aspek keaslian pada kedua kelas menunjukkan hasil yang paling rendah, hal ini dikare- nakan kebiasaan siswa dalam pembelajaran yang masih berpedoman pada guru dan jarang melakukan praktikum, sehingga kemampuan kreativitas aspek keaslian yang diteliti ketika menyimpulkan hasil percobaan membuat siswa kesulitan karena belum terbiasa dengan pembelajaran yang melakukan percobaan dan diskusi serta menyimpulkan hasil pembelajaran. Pedoman siswa yang memperoleh informasi pembelajaran dari guru karena metode yang digunakan di sekolah tersebut yang masih konvensional (ceramah) menghambat siswa dalam memunculkan aspek kreativitasnya terutama keaslian/originality.Sejalan dengan penelitian Argarini, Budiyono, \& Sujadi (2014) Keterbatasan siswa dalam mengembangkan diri dan kreativitasnya dikarenakan ketergantungan terhadap pedoman yang diberikan.

Pada kelas eksperimen dan kelas kontrol yang sama-sama menggunakan metode eksperimen dan penemuan konsep secara mandiri dari siswa dapat mengukur kreativitas siswa di kedua kelas, hal ini sejalan dengan penelitian yang dilakukan oleh Santofani \& Rosana (2016) melalui pembelajaran dengan pendekatan inquiry dapat meningkatkan kreativitas siswa dengan tes.

Penelitian ini menunjukkan model pembelajaran IPA berbasis kearifan lokal terbukti berpengaruh terhadap kreativitas dan hasil belajar siswa. Dapat dilihat dari uji $t$-test data posttest kedua kelas menghasilkan taraf signifikansi 0,000. Dapat ditarik kesimpulan bahwa implementasi model pembelajaran IPA berbasis kearifan lokal dapat mempengaruhi kreativitas siswa. Sejalan dengan penelitian Suastra, Tika, \& Kariasa (2011) melalui implementasi model pembelajaran sains berbasis budaya lokal berpengaruh terhadap kompetensi dasar siswa yang diukur dengan uji ANAVA dan menghasilkan taraf signifikansi 0,000 yang dapat ditarik interprestasi model pembelajaran sains berbasis budaya lokal dapat mempengaruhi kompetensi dasar siswa. Kompetensi dasar sains pada penelitian ini diukur dengan tes hasil belajar siswa yang memuat materi hasil pembelajaran.

Pengaruh yang kedua dilihat dari data lembar observasi ketika pembelajaran. Hasil analisis data lembar observasi menunjukkan melalui model pembelajaran IPA berbasis kearifan lokal dapat meningkatkan kreativitas siswa ketika pembelajaran yang terdiri dari 3 pertemuan. Sejalan dengan penelitian yang dilakukan oleh Utami, Noviar, \& Agustina 
(2012) model pembelajaran sains berbasis kearifan lokal dengan teknik klarifikasi nilai yang terdiri dari 2 siklus dapat mempengaruhi kreativitas siswa. Peningkatan kreativitas pada penelitian tersebut menghasilkan nilai $\mathrm{N}$ gain sebesar 0,15 kategori rendah.

Pada penelitian ini peningkatan kreativitas siswa yang dilihat dari hasil tes menunjukkan $\mathrm{N}$ gain nilai pretest dan posttest sebesar 0,46 berkategori sedang. Hal ini menunjukkan bahwa penelitian yang telah dilakukan mendapatkan hasil yang lebih baik dari sebelumnya. Berdasarkan penelitian yang diperoleh dapat disimpulkan bahwa implementasi model pembelajaran IPA berbasis kearifan lokal dapat meningkatkan kreativitas siswa. Sejalan dengan hasil penelitian Suatra \& Yasmini (2013) kreativitas berpikir siswa dapat dikembangkan melalui implementasi model pembelajaran berbasis kearifan lokal yang menggali karakter bangsa.

Pada penelitian ini menunjukkan kreativitas siswa yang merupakan karakter positif yang harus ada dalam pendidikan sains perlu dikembangkan dengan kebutuhan berkembangnya sikap kreatif ilmiah siswa dalam menghadapi arus global yang sudah maju. Serupa dengan penelitian yang dilakukan oleh Subali, Sopyan, \& Ellianawati (2015) melalui desain model pembelajaran sains berbasis local wisdom dapat meningkatkan karakter positif siswa. Penelitian Subali, Sopyan, \& Ellianawati (2015) tidak memfokuskan pengembangan karakter kreatif sedangkan pada penelitian ini memfokuskan pada karakter kreativitas beserta aspek-aspek kreativitasnya.

Keseluruhan aspek kreativitas yang meliputi aspek kelancaran, keaslian, keluwesan, kesadaran dan ingatan yang diteliti menunjukkan hasil yang meningkat. Hal ini serupa dengan penelitian Suastra \& Yasmini (2013) terdapat beberapa aspek kreativitas siswa seperti kelancaran, keaslian dan ingatan yang dapat dikembangkan melalui pembelajaran sains berbasis kearifan lokal. Pada penelitian ini aspek kreativitas yang dikembangkan adalah aspek kelancaran, keluwesan, keaslian, kesadaran dan ingatan.

Besar peningkatan hasil belajar siswa setelah diimplementasikan model pembelajaran IPA berbasis kearifan lokal dapat dilihat dari data pretest dan posttest. Pada kelas eksperimen rata-rata nilai pretest sebesar 27,0 dan rata-rata nilai posttest sebesar 78,4 Sedangkan pada kelas kontrol rata-rata nilai pretest 29,6 dan rata-rata nilai posttest 68,9 .

Berdasarkan data tersebut pada kedua kelas dilakukan uji gain ternormalisasi untuk mengetahui besarnya peningkatan hasil belajar siswa setelah diberi perlakuan. Hasil belajar siswa pada kelas eksperimen meningkat sebesar 0,70 dengan kategori sedang dan pada kelas kontrol hasil belajar siswa meningkat sebesar 0,56 dengan kategori sedang.

Kedua kelas mengalami peningkatan dengan kategori sedang yang menunjukkan bahwa hasil belajar siswa meningkat di kedua kelas. Kedua kelas menggunakan model pembelajaran yang berbeda pada kelas eksperimen menggunakan model pembelajaran IPA berbasis kearifan lokal sedangkan pada kelas kontrol menggunakan model pembelajaran pendekatan saintifik.

Meskipun sama-sama berkategori sedang, tetapi hasil $\mathrm{N}$-gain hasil belajar siswa pada kelas eksperimen lebih tinggi daripada kelas kontrol. Hal ini dikarenakan model pembelajaran yang dilakukan pada kedua kelas berbeda. Melalui pembelajaran IPA berbasis kearifan lokal yang diterapkan pada kelas eksperimen dapat meningkatkan kreativitas siswa aspek keluwesan.

Soal posttest meneliti kemampuan siswa dalam memecahkan permasalahan terkait materi yang telah dipelajari siswa setelah proses pembelajaran siswa dalam memecahkan soal yang disajikan. Jawaban siswa pada kelas eksperimen lebih luas dan perspektif terhadap objek permasalahan materi pembelajaran dalam sudut pandang ilmu sebagai hasil pengetahuan sains dan sebagai hasil pengetahuan masyarakat dalam bentuk kearifan lokal. Hal ini menunjukkan bahwa implementasi model pembelajaran IPA berbasis kearifan lokal dapat meningkatkan hasil belajar siswa dalam memecahan permasalahan yang disajikan dalam soal. Sejalan dengan penelitian Mungmachon (2012) melalui kearifan dan pengetahuan lokal yang terintegrasi dalam ilmu pengetahuan alam mampu memecahkan suatu permasalahan yang disajikan.

Besar peningkatan kreativitas siswa diteliti dari tiga kali pertemuan dengan uji gain ternormalisasi seperti yang ditunjukkan pada Tabel 6 dan 7. Berdasarkan Tabel 6 dan 7 menunjukkan indikator aspek kreativitas siswa pada kelas eksperimen yang meliputi aspek keluwesan, kelancaran, keaslian, kesadaran dan ingatan dengan kategori sedang sedangkan pada kelas kontrol indikator aspek kreativitas kelan- 
caran dan keluwesan yang mengalami peningkatan dengan kategori sedang, sedangkan indikator aspek kreativitas aspek keaslian, ingatan dan kesadaran mengalami peningkatan dengan kategori rendah.

Meskipun peningatan kreativitas siswa pada kelas kontrol lebih rendah, namun pada kelas kontrol mengalami peningkatan kreativitas dari sebelum dan sesudah pembelajaran. Kelas kontrol yang menggunakan model pembelajaran pendekatan saintifik yang terdiri atas tahapan mengamati, menanya, mencoba, mengolah dan mengomunikasikan dirancang dalam pembelajaran diskusi dan melakukan percobaan mengalami peningkatan kreativitas siswa.

Peningkatan kreativitas siswa pada kelas eksperimen yang lebih tinggi menunjukkan bahwa melalui implementasi model pembelajaran IPA berbasis kearifan lokal mampu meningkatkan kreativitas siswa yang lebih baik dari kelas kontrol. Pembelajaran pada kelas kontrol dengan model pembelajaran pendekatan saintifik hanya berfokus pada materi pembelajaran saja, berbeda dengan kelas eksperimen yang lebih luas karena mengaitkan kearifan lokal masyarakat dalam bentuk tabel kalender pranata mangsa. Hal ini sejalan dengan penelitian Suastra, Tika, \& Kariasa (2011) pembelajaran berbasis budaya lokal mampu menjembatani sains asli yang dimiliki oleh siswa dengan sains yang diperoleh di sekolah.

Peningkatan kreativitas pada kelas eksperimen dan kelas kontrol yang tidak terlalu signifikan di karenakan kedua kelas menggunakan pembelajaran yang memiliki tujuan dan tahapan yang hampir mirip yaitu memfokuskan pada siswa sebagai subjek belajar dan mengarahkan siswa untuk memperoleh pengetahuan berdasarkan percobaan. Kemiripan juga terdapat pada lembar kegiatan siswa, hanya saja lembar kegiatan siswa pada kelas eksperimen dibantu dengan nilai-nilai kearifan lokal yang ada di masyarakat dan kalender pranata mangsa.

\section{SIMPULAN}

Model pembelajaran IPA berbasis kearifan lokal memberikan pengaruh terhadap kreativitas dan hasil belajar siswa dilihat dari perbedaan yang signifikan hasil rata-rata kreativitas dan hasil belajar siswa pada kelas eksperimen dan kelas kontrol yang diteliti dengan lembar observasi dan tes.

Secara keseluruhan besar peningkatan kreativitas siswa yang terdiri atas aspek kelancaran (fluency), keluwesan (flexibility), keaslian (originality), ingatan (memory), dan kesadaran (awarness) pada kelas eksperimen sebesar 0,46 dengan kategori sedang. Sedangkan pada kelas kontrol besar peningkatan kreativitas siswa sebesar 0,32 dengan kategori sedang, sedangkan besar peningkatan hasil belajar siswa pada kelas eksperimen sebesar 0,70 dalam kategori sedang dan pada kelas kontrol sebesar 0,56 dalam kategori sedang.

Berdasarkan hasil penelitian saran yang peneliti berikan adalah sebagai berikut: Pertama, model pembelajaran IPA berbasis kearifan lokal pada siswa SMP disarankan untuk dapat diimplementasikan di daerah yang memiliki potensi kearifan lokal yang dapat dimasukan sebagai bahan pembelajaran IPA khususnya daerah seperti gunungpati dan sekitarnya yang masih dominan memegang prinsip kearifan lokal. Kedua, alokasi waktu dipersingkat dalam pembuatan karya agar pembelajaran bisa berlangsung lebih lama dan mendalam serta alangkah lebih baik siswa juga diberi penugasan di rumah untuk mengembangkan kreativitasnya selain di dalam kelas. Ketiga, guru yang akan membentuk kreativitas siswa hendaknya tidak hanya melihat aspek kreativitas kelancaran, keluwesan, keaslian, kesadaran dan ingatan saja. Akan tetapi juga hasus melihat aspek lainnya seperti mengelaborasi, evaluasi dan percaya diri.

\section{DAFTAR PUSTAKA}

Argarini, D. F., Budiyono, B., \& Sujadi, I. (2014). Karakteristik berpikir kreatif siswa kelas VII SMP N 1 Kragan dalam memecahkan dan mengajukan masalah matematika materi perbandingan ditinjau dari gaya kognitif. Journal on Mathematics and Mathematics Education, 4(2). Retrieved from http://jurnal.fkip.uns.ac.id/index.php/jmm e/article/view/5301

Canadian Council on Learning. (2008). Lessons and learning. Retrieved from http://en.copian.ca/library/research/ccl/be nefits_learning/benefitslearning.pdf

Hamid, A. A. (2011). Pembelajaran fisika di sekolah: Apa dan bagaimana pendekatan generik dan metode iqra dilaksanakan dalam pembelajaran fisika. Yogyakarta.

Hu, W., \& Adey, P. (2002). A scientific creativity test for secondary school students. International Journal of Science Education, 24(4), 389-403. https://doi.org/10.1080/095006901100989 


\section{Jurnal Inovasi Pendidikan IPA, 3 (2), 2017 - 127}

Aji Pamungkas, Bambang Subali, Suharto Lunuwih

12

Hu, W., Wu, B., Jia, X., Yi, X., Duan, C., Meyer, W., \& Kaufman, J. C. (2013). Increasing students' scientific creativity: The "Learn to think" intervention program. The Journal of Creative Behavior, 47(1), 3-21. https://doi.org/10.1002/jocb.20

Lee, M., \& Erdogan, I. (2007). The effect of science-technology-society teaching on students' attitudes toward science and certain aspects of creativity. International Journal of Science Education, 29(11), 1315-1327.

https://doi.org/10.1080/095006906009729 74

Mariana, I. M. A., \& Praginda, W. (2009). Hakikat IPA dan pendidikan IPA. Bandung: Pusat Pengembangan dan Pemberdayaan Pendidik dan Tenaga Kependidikan Ilmu Pengetahuan Alam.

Mungmachon, M. R. (2012). Knowledge and local wisdom: Community treasure. International Journal of Humanities and Social Science, 2(13), 174-181. Retrieved from

http://www.ijhssnet.com/journals/Vol_2 No_13_July_2012/18.pdf

Santofani, A., \& Rosana, D. (2016). Pengembangan tes kreativitas pada pembelajaran fisika dengan pendekatan inkuiri pada materi teori kinetik gas. Jurnal Inovasi Pendidikan IPA, 2(2), 134. https://doi.org/10.21831/jipi.v2i2.6373

Setiawan, A. (2014, June 13). Pengembangan modul ipa terpadu berbasis sainsteknologi-masyarakat dengan tema pembuatan kompos sebagai sarana berpikir kreatif siswa SMP/MTs. UIN Sunan Kalijaga Yogyakarta. Retrieved from http://digilib.uin-suka.ac.id/13212/

Suastra, I. W., Tika, K., \& Kariasa, N. (2011). Efektivitas model pembelajaran sains berbasis budaya lokal untuk mengembangkan kompetensi dasar sains dan nilai kearifan lokal di SMP. JPPP Lemlit, 5(3), 258-273. Retrieved from https://ejournal.undiksha.ac.id/index.php/J $\mathrm{JL} /$ article/view/144

Suastra, I. W., \& Yasmini, L. P. B. (2013). Model pembelajaran fisika untuk mengembangkan kreativitas berpikir dan karakter bangsa berbasis kearifan lokal Bali. JPI (Jurnal Pendidikan Indonesia), 2(2), 221-235. https://doi.org/10.23887/jpiundiksha.v2i2.2166

Subagia, I. W., \& Wiratma, I. G. L. (2008). Penerapan model siklus belajar berbasis tri pramana pada pembelajaran sains di sekolah. Jurnal Pendidikan Dan Pengajaran Undiksha, 41(2).

Subali, B., Sopyan, A., \& Ellianawati, E. (2015). Developing local wisdom based science learning design to establish positive character in elementary school. Jurnal Pendidikan Fisika Indonesia, 11(1), 1-7. https://doi.org/10.15294/jpfi.v11i1.3998

Subekti, Y., \& Ariswan, A. (2016). Pembelajaran fisika dengan metode eksperimen untuk meningkatkan hasil belajar kognitif dan keterampilan proses sains. Jurnal Inovasi Pendidikan IPA, 2(2), 252. https://doi.org/10.21831/jipi.v2i2.6278

Sufren, S., \& Natanael, Y. (2014). Belajar otodidak SPSS pasti bisa (Indonesian Edition). Jakarta: Elex Media Komputindo.

Sugiyono. (2015). Metode penelitian pendidikan: Pendekatan kuantitatif, kualitatif, dan $R \& D$. Bandung: Alfabeta.

Trianto, T. (2007). Model-model pembelajaran inovatif berorientasi Konstruktivistik. Jakarta: Prestasi Pustaka.

Utami, R. P., Noviar, D., \& Agustina, E. H. (2012). Aplikasi model VCT (Value Clarification Technique) berbasis local wisdom sebagai upaya internalisasi pendidikan karakter untuk meningkatkan kreativitas berpikir dan hasil belajar biologi siswa. Prosiding Seminar Biologi, 9(1). Retrieved from http://jurnal.fkip.uns.ac.id/index.php/pros bio/article/view/1030

Wibowo, A., \& Gunawan. (2015). Pendidikan karakter berbasis kearifan lokal di sekolah (konsep, strategi, dan implementasi). Yogyakarta: Pustaka Pelajar.

Wisudawati, A. W., \& Sulistyowati, E. (2014). Metodologi pembelajaran IPA. Jakarta: Bumi Aksara. 